SINAI Journal of Applied Sciences (ISSN: 2314-6079) Vol. (8) Is. (2), Aug. 2019

Screened BY SINAI Journal of Applied Sciences

\title{
EFFECT OF PLANT GROWTH PROMOTING RHIZOBACTERIA AND SALINITY LEVELS ON TOMATO PLANT GROWTH USING $\mathbf{N}^{15}$ TECHNIQUE
}

\author{
Ahmed A. Hassan ${ }^{*}$, E.M. El-Tantawy ${ }^{2}$, E.M.A. Thabet ${ }^{1}$ and A.I. El-Kassas ${ }^{2}$ \\ 1. Dept. Plant Res., Cent. Nuclear Res., Authority Atomic Energy, Egypt. \\ 2. Dept. Plant Prod., Fac. Environ. Agric. Sci., Arish Univ., Egypt.
}

\begin{abstract}
Pot experiments were conducted at the Experimental Greenhouse at Nuclear Research Center, Atomic Energy Authority, Egypt, during the two growing seasons of 2017 and 2018 for studying the effect of soil salinity levels and inoculation with Rhizobacteria on improving tomato (hybrid "Anfoway $\mathrm{F}_{1}$ ") plant growth and its productivity, using salty soil of Ras-Sudr, South Sinai Governorate. Saline treatments were prepared as follows: A) In the first season (2017), three saline treatments were used In the second season 2018, four saline treatments were used Rhizobacteria treatments were as follows: A) In the first season: 1) control (pots without inoculation with Rhizobacteria); 2) inoculation with Azosperillum sp.; 3) inoculation with Azotobacter sp.; 4) inoculation with a mixture from Azosprillum sp.+ Azotobacter sp.; B) In the second season: 1) control, (pots without inoculation with Rhizobacteria); 2) inoculation with a mixture from Azosprillum sp.+ Azotobater sp. Ammonium sulphate as a nitrogen fertilizer have an atom excess of $2 \% \mathrm{~N}$ at a rate of $2.14 \mathrm{~g} /$ pot were used to measure nitrogen derived from fertilizer and then determine the fertilizer- $\mathrm{N}$ yield by tomato plant. Treatments were arranged randomly in a factorial experiment with a randomized complete block design included four replicates for each treatment. Results indicated that plants grown under low salinity $\left(0.3 \mathrm{dSm}^{-1}\right)$ and applicated by plant growth promoting bacteria (PGPR) had increased number of leaves/plants, number of branches/plants compared with that grown in high salinity and did not applicated with PGPR. The interaction between high levels of salinity (6.6 and 5.8 $\mathrm{dSm}^{-1}$ ) and each of Azotobacter and Azosprillium increased total chlorophyll in tomato leaves significantly compared to the leaves untreated with PGPR. Inoculation by plant growth promoting rhizobacteria (PGPR) with the low level of salinity $\left(0.3 \mathrm{dSm}^{-1}\right)$ increased number of flowers per plant compared to its same interaction with the high level of salinity $\left(3.6 \mathrm{dSm}^{-1}\right)$. The effect of interaction between Rhizobacteria and soil salinity on nitrogen labeled showed a significant increment at all salinity levels and all Rhizobacteria forms. Nitrogen derived from ammonium sulphate by tomato plants were improved significantly with treating soil by Rhizobacteria. Plant growth promoting rhizobacteria in different forms increased significantly fertilizer nitrogen yield (FNY) and nitrogen use efficiency in tomato plants.
\end{abstract}

Key words: Tomato, salinity, plant growth promoting rhizobacteria (PGPR, Ndff (\%), $\mathrm{N}$-utilized (\%), atom excess.

\section{INTRODUCTION}

Saline soil which having a high concentration of soluble salts high enough to inhibit plant growth and then decreased yield. Irrigated land that is salt affected area in Egypt reached about one million hectares (about 2.25 million faddan). Shrivatava and Kumar (2015) reported that for all important crops, average yield is only a

\footnotetext{
* Corresponding author: Tel.: +201013383603

E-mail address: ahmed29amar5@gmail.com
} 
fraction somewhere between 20 and $50 \%$ of record yields; these losses were due to drought and high soil salinity.

For tomato, it was found that the highest water absorption was obtained at low EC values while the nutrients uptake was found to be the highest at high EC values (Voogt, 1987). Pessarakli and Tucker (1988) showed that nitrogen uptake might also be affected by high $\mathrm{NaCl}$ salinity in tomato plants, whereas, for 21 days-old tomato plants, nitrogen 15 uptake was reduced at 0.6 and $0.9 \mathrm{MPa}$ osmotic potentials with $\mathrm{NaCl}(140-200 \mathrm{Mm} \mathrm{NaCl})$.

Martinez and Cerda (1989) found a reduction in the nitrate reductase activity of tomato leaves with an increase of salinity $(\mathrm{NaCl})$, while, Al-Rawahy et al. (1990) observed a lower dry matter production and nitrogen uptake under saline stress by $\mathrm{NaCl}$. Also, increases in salinity (under high ECs) induced an increase in tomato fruits dry matter linearly (Krinsky, 1991). Adams and Ho (1995) mentioned that under different growing conditions, increasing the salinity from 3 to 5.5 and $8 \mathrm{dSm}-1$, reduced $\mathrm{K}^{+}$uptake by $27 \%$ and $36 \%$, respectively, while, it caused a less important reduction in the uptake of water ( 7 and 15\%) and $\mathrm{Ca}^{++}(5$ and $15 \%)$.

Numerous studies by Lopez and Satti (1996) and Lopez (1998) indicated that $\mathrm{K}^{+}$ concentration in tomato plant tissues expressed on a dry weight basis, as the $\mathrm{Na}^{-}$ salinity or as the $\mathrm{Na}^{+}: \mathrm{Ca}^{++}$ratio in the root media increases as a consequence of a competitive uptake processes as a result in growth and yield reduction.

Plant growth promoting rhizobacteria (PGPR promote plant growth as a result of a symbiotic N2 fixation (Boddey and Dobereiner, 1995), solubilization of mineral phosphate and other nutrients (De Freitas et al., 1997), solubization of phosphorus in the soil (Rodringuez and Fraga, 1999), and the production of indoleacetic acid (IAA) in the roots (Aloni et al., 2006).

A significant increase in tomato and pepper transplants growth occurred in response to most formulations of plant growth promoting Rhizobacteria such as stem dry weight, leaf area, stem length and diameter, root dry weight and number of true leaves (Kokalis-Burelle et al., 2002). Rhizosphere microorganisms, particularly beneficial bacteria and fungi can improve plant performance under stress environments and enhance yield both directly and indirectly (Dimkpa et al., 2009). Some plant growth-promoting rhizobacteria (PGPR) can stimulate plant growth by providing plants with nitrogen available nutrients and phytohormones and soluble phosphate (Hayat et al., 2010).

Plant growth and fertilizer use efficiency of tomato plants improved as a result of using PGPR as a mixture strains into a soil at $75 \%$ fertilizer rate and the yield was similar to that at $100 \%$ fertilizer rate (Adesemoye et al., 2009). So, it is very important to study the role of different formulations of microorganisms considered as a plant growth promoting rhizobacteria in improving tomato plant growth in saline soil specially in Ras-Sudr region as an important aim and assistant objective.

\section{MATERIALS AND METHODS}

Ras-Sudr soil which characterized as relatively saline soil has been treated and mixed by sandy soil having less saline for diluting and giving a soil suitable for tomato plants to grow well if possible. Pot experiments were conducted at the Experimental Greenhouse at the Nuclear Research Center, Atomic Energy Authority, Egypt, during the two growing seasons of 2017 and 2018 to study effect of application of plant growth promoting rhizobacteria on salinity soil in improving tomato plant growth if possible. 


\section{Salinity Treatments}

In the first growing season, the crude soil presented from Ras-Sudr was mixed with sandy soil for developing the salinity cases as following:

1. Crude soil of Ras-Sudr ( $9 \mathrm{~kg} / \mathrm{pot}$ ) having Ec of $6.6 \mathrm{dSm}^{-1}$.

$2.75 \%$ crude soil of Ras-Sudr $(6.75 \mathrm{~kg})+$ $25 \%$ sand $(2.25 \mathrm{~kg})$ having Ec of 5.8 $\mathrm{dSm}^{-1}$.

$3.50 \%$ crude soil of Ras-Sudr $(4.5 \mathrm{~kg})+50 \%$ sand $(4.5 \mathrm{~kg})$ having Ec of $4.4 \mathrm{dSm}^{-1}$.

In the second growing season, four saline cases of soil were presented by mixing Ras-Sudr crude soil by sand to develop the following treatments:

1. Nine kilograms of sand per/pot having Ec of $0.3 \mathrm{dSm}^{-1}$,

2. 8900 grams of sand were mixed with a 100 gram of Ras-Sudr crude soil for every pot $(9 \mathrm{~kg} /$ pot$)$ having ${ }^{1} \mathrm{Ec}$ of 1.4 $\mathrm{dSm}^{-1}$

3. 8800 grams of sand was mixed with a 200 gram of Ras-Sudr crude soil for every pot $(9 \mathrm{~kg} / \mathrm{pot})$ having Ec of 1.9 $\mathrm{dSm}^{-1}$, and

4. 8700 grams of sand was mixed with a 300 gram of Ras-Sudr crude soil for every pot $(9 \mathrm{~kg} /$ pot $)$ having Ec of 3.6 $\mathrm{dSm}^{-1}$.

Ras-Sudr soil which are characterized as a salty soil and having the chemical analysis presented in Table 1 was treated to some extent by using sandy soil (Table 2).

\section{Plant Growth Promoting Rhizobacteria Treatments}

In the first season (2017), Rhizobacteria treatments were:

1. Control (without rhizobacteria inoculation),

2. Inoculation with Azosprillum sp.

3. Inoculation with Azotobacter sp., and
4.Inoculation with a mixture of Azosprillum spp. with Azotobacter spp.

In the second growing season (2018), Rhizobacteria treatments were:

1. Control (without rhizobacteria inoculation) and

2. Inoculation with a mixture of Azosprillum spp + Azotobacter spp.

Seedlings of tomato cv. "Anfoway $\mathrm{F}_{1}$ " were transplanted in pots (one seedling/pot) on $12^{\text {th }}$ March in 2017 and $26^{\text {th }}$ Feb. 2018.

Nitrogen Fertilization of tomato started 27 days after transplanting throw the irrigation system (Fertigation) at rate of $300 \mathrm{~kg}$ ammonium sulphate/ Fad., where, the quantity was divided to ten doses added along the season at 15 days interval. Ammonium sulphate as a tracer technique $\left(10 \%\right.$ labeled $\left.\mathrm{N}^{15}\right)$ was used to evaluate the $\mathrm{N}$-utilized by tomato plant under the application of plant growth promoting Rhizobacteria. Ammonium sulphate 10\% atom excess was diluted by ordinary ammonium sulphate to be $2 \%$ according to the procedure by IAEA (2001). The Dumas dry combustion method (Fiedler and Proksch,1975) was used to convert nitrogen compound in dry sample into nitrogen gas. Nitrogen atom excess was measured in plant sample by emission spectrometer $\mathrm{N}^{15}$ analyzer (Model NOI6PC) according to the description of IAEA (2001). The following equation was used in accounting $\mathrm{N}^{15}$ characteristics:

Then, the amount of $\mathrm{N}$ derived from fertilizer found in plant is according to the following equation:

$\%$ Nitrogen derived from fertilizer $(\% \mathrm{Ndff})$ $=\%{ }^{15} \mathrm{~N}$ atom excess in plant sample $\times 100$ $\%{ }^{15} \mathrm{~N}$ atom excess in fertilizer $(2 \%)$

$\operatorname{Ndff}(g /$ area $)=\operatorname{Ndff}(\%) \times$ total $N$ uptake $(g /$ area $)$

Then, the recovery of fertilizer $\mathrm{N}(\mathrm{N}$ utilized) is the percentage of $\mathrm{N}$ derived 
Table (1): Initial mechanical and chemical analyses of Ras Sudr soil (a) Mechanical analysis

\begin{tabular}{ccccc}
\hline \multirow{2}{*}{$\begin{array}{c}\text { Soil depth } \\
(\mathbf{c m})\end{array}$} & \multicolumn{3}{c}{ Particle size distribution (\%) } & \multirow{2}{*}{ Texture class } \\
\cline { 2 - 4 } & Sand & Silt & Clay & \\
\hline $\mathbf{0 - 1 5}$ & 75.00 & 22.40 & 2.60 & Sandy loam \\
$\mathbf{1 5}-\mathbf{3 0}$ & 90.85 & 8.75 & 0.40 & Sandy \\
$\mathbf{3 0}-\mathbf{4 5}$ & 95.60 & 3.60 & 0.80 & Sandy \\
$\mathbf{4 5}-\mathbf{6 0}$ & 96.40 & 2.80 & 0.80 & Sandy \\
\hline
\end{tabular}

(b) Chemical analysis

\begin{tabular}{|c|c|c|c|c|c|c|c|c|c|c|c|c|}
\hline \multirow[t]{2}{*}{ Depth } & \multirow{2}{*}{$\begin{array}{l}\text { Saturation } \\
\text { percentage }\end{array}$} & \multirow[t]{2}{*}{ pH } & \multicolumn{4}{|c|}{$\begin{array}{l}\text { Soluble cations } \\
\quad\left(\text { meq. }\left.\right|^{-1}\right)\end{array}$} & \multicolumn{3}{|c|}{$\begin{array}{l}\text { Soluble anions } \\
\quad\left(\text { meq. } ~^{\left.I^{-1}\right)}\right.\end{array}$} & \multicolumn{3}{|c|}{$\begin{array}{c}\text { Average } \\
\text { nutrients } \\
\text { (ppm) }\end{array}$} \\
\hline & & & $\mathbf{K}^{+}$ & $\mathrm{Na}^{+}$ & $\mathbf{M g}^{++}$ & $\mathrm{Ca}^{++}$ & $\mathrm{SO}_{4}^{--}$ & $\mathrm{Cl}^{-} \mathrm{HCO}$ & $\mathrm{CO}_{3}^{-}$ & $\mathbf{K}$ & $\mathbf{P}$ & $\mathbf{N}$ \\
\hline $30 \mathrm{c}$ & 22.0 & $\overline{7.94}$ & 23.0 & 20.0 & 82.97 & 1.03 & - & $4.0 \quad 60.0$ & 63.0 & 79.2 & 9.4 & 96.7 \\
\hline
\end{tabular}

Table (2): Mean properties of sandy soil

\begin{tabular}{|c|c|c|c|c|}
\hline $\begin{array}{l}\mathrm{pH} \\
(1: 2.5)\end{array}$ & $\begin{array}{l}\text { EC 'pe'* } \\
\left(\mathrm{dS} \mathrm{m}^{-1}\right)\end{array}$ & $\begin{array}{l}\mathrm{CaCO}_{3} \\
\left(\mathrm{~g} \mathrm{~kg}^{-1}\right)\end{array}$ & $\begin{array}{c}\text { Organic matter } \\
\left(\mathrm{gkg}^{-1}\right)\end{array}$ & $\begin{array}{l}\text { Saturation } \\
\text { (SP) }(\%)\end{array}$ \\
\hline 7.23 & 3.14 & 0.0 & 0.3 & 21.47 \\
\hline \multicolumn{5}{|c|}{ Soluble Ions (meq. ${ }^{-1}$ ) } \\
\hline 0.0 & $\mathrm{Na}^{+}$ & 6.8 & $\mathrm{CO}_{3}{ }^{2-}$ & 0.0 \\
\hline 9.3 & $\mathrm{~K}^{+}$ & 3.6 & $\mathrm{HCO}^{3-}$ & 9.3 \\
\hline 8.5 & $\mathrm{Ca}^{2+}$ & 14.6 & $\mathrm{Cl}^{-}$ & 8.5 \\
\hline 13.6 & $\mathrm{Mg}^{2+}$ & 6.4 & $\mathrm{SO}_{4}^{2-}$ & 13.6 \\
\hline \multicolumn{5}{|c|}{ Available nutrients ${ }^{*}\left(\mathrm{mg} \mathrm{kg}^{-1}\right)$} \\
\hline $\mathrm{K}$ & $\mathrm{Fe}$ & $\mathrm{Mn}$ & $\mathrm{Zn}$ & $\mathrm{Cu}$ \\
\hline 0.2 & 25.8 & 0.5 & 1.4 & 1.4 \\
\hline \multicolumn{5}{|c|}{ Total nutrients $\left(\mathrm{g} \mathrm{kg}^{-1}\right)$} \\
\hline $\mathrm{K}$ & $\mathrm{Fe}$ & $\mathrm{Mn}$ & $\mathrm{Zn}$ & $\mathrm{Cu}$ \\
\hline 1.00 & 2.20 & 0.01 & 0.10 & 0.20 \\
\hline \multicolumn{5}{|c|}{ Particle size distribution (\%) } \\
\hline Texture & Sand & Silt & Clay & Texture \\
\hline Sand & 98.0 & 2.0 & 0.0 & Sand \\
\hline
\end{tabular}


from fertilizer found in plant as a portion of the amount of $\mathrm{N}$ applied as a fertilizer. The equation is as follows:

N-utilized $(\%)=\frac{\text { Ndff }}{\text { Rate of fertilzer N }} \times 100$

Where:

Ndff is the amount of fertilizer $\mathrm{N}$ found in plant ( $\mathrm{g} /$ plant), and Rate of fertilizer $\mathrm{N}$ is the amount of applied fertilizer $\mathrm{N}$ (g/area) (2.14 gm AS)

\section{Characters studied}

1. Number of leaves, branches, and number of flowers per plant after 15 days from the application of PGPR as well as chlorophyll content after 30 days from PGPR application using Minolta SPAD502 chlorophyll meter,

2. Shoots and roots dry weight at harvest (g/plant),

3. Nitrogen percentage in plant sample at harvest as described by Jones et al. (1991).

4. Phosphorus content in plant sample $(\mathrm{g} / \mathrm{kg}$. dry matter) dry matter was measured according to the method described by Cottine et al. (1982). using UV -VIS spectrometer at $430 \mathrm{~nm}$,

5. Potassium content ( $\mathrm{g} / \mathrm{kg}$. dry matter) in plant sample was determined using atomic absorption spectrometer, and

6. $\mathrm{N}^{15 \%}$ atom excess in plant sample according to the procedure described by the IAEA (2001) to determine nitrogen derived from fertilizer and $\mathrm{N}$-utilized in tomato plant.

Treatments were arranged randomly in a factorial experiment with a randomized complete block design included four replicates for each treatment. Data observed

were statistically analyzed according to Steel and Torrie (1960). The significant difference (Least Significant Differences) were measured at $1 \%$ according to Snedecor and Cochran (1980).

\section{RESULTS AND DISCUSSION}

\section{Growth Characters}

\section{Number of Leaves Per Plant}

Results in Table 3 show insignificant effects for salinity levels and plant growth promoting rhizobacteria (PGPR) on number of leaves per plant. On other hand, plants grown under low salinity $\left(0.3 \mathrm{dS} \mathrm{m}^{-1}\right)$ and applicated by PGPR had increased number of leaves/plants compared with that grown in high salinity and did not applicated with PGPR, where, the increment reached $78.5 \%$.

\section{Number of Branches/Plant}

Results in Table 4 show insignificant effects for salinity levels and plant growth promoting rhizobacteria (PGPR) on number of tomato branches. Number of tomato branches was increased significantly after 10 days from addition of PGPR to the plants through the two growing seasons, the increment in branches number reached about $10 \%$ in the second season. On the other side, a significant effect due to salinity in soil was observed on number of branches, whereas, it decreased significantly in the second growing season and reached about $8.97,24.97$ and $37.17 \%$ for $1.4,1.9$ and $3.6 \mathrm{dSm}^{-1}$ of soil salinity, respectively, compared to the $0.3 \mathrm{dS} \mathrm{m}$ of soil salinity. The same trend of salinity treatment was shown through the results of the first season, whereas, the increasing in salinity levels decreased number of branches.

The decrement reached 16.32 and $15.81 \%$ for 4.4 and $5.8 \mathrm{dSm}^{-1}$ compared to the levels of $6.6 \mathrm{dsm}^{-1}$. The interaction between saline treatment and plant growth promoting rhizobacteria on number of branches per tomato plant did not indicate significantly difference in the two growing seasons but it could be said that, at low level of salinity PGPR increased number of branches/plants in the two growing seasons. 
Table (3): Effect of soil salinity and application of promoting rhizobacteria (PGPR) on number of tomato leaves in 2017 and 2018 seasons.

a) The first growing season (2017)

\begin{tabular}{lcccc}
\hline \multicolumn{1}{c}{$\begin{array}{c}\text { Rhizobacteria } \\
\text { treatment }\end{array}$} & \multicolumn{3}{c}{ Soil Salinity* $\left(\mathbf{d S m}^{-\mathbf{1}}\right)$} & $\begin{array}{c}\text { Average of } \\
\text { Rhizobacteria }\end{array}$ \\
\cline { 2 - 4 } & $\mathbf{6 . 6}$ & $\mathbf{5 . 8}$ & $\mathbf{4 . 4}$ & \\
\hline Control & 19.50 & 20.50 & 23.00 & 21.00 \\
Azosprillum spp. & 19.25 & 21.50 & 18.50 & 19.75 \\
Azootobacter spp. & 23.00 & 18.00 & 18.50 & 19.83 \\
Azoto + Azospril spp. & 19.25 & 18.25 & 24.25 & 20.29 \\
Average of salinity & 20.25 & 19.56 & 21.07 & \\
\hline
\end{tabular}

Means of salinity effects were NS Means of Rhizobacteria effects were NS LSD at 1\% for interaction means was 5.0

b) The second growing season (2018)

\begin{tabular}{|c|c|c|c|c|c|}
\hline \multirow{2}{*}{$\begin{array}{c}\text { Rhizobacteria } \\
\text { treatment }\end{array}$} & \multicolumn{4}{|c|}{ Soil salinity* $\left(\mathrm{dSm}^{-1}\right)$} & \multirow{2}{*}{$\begin{array}{l}\text { Average of } \\
\text { rhizobacteria }\end{array}$} \\
\hline & 0.3 & 1.4 & 1.9 & 3.6 & \\
\hline Control & 27.50 & 25.00 & 20.75 & 17.50 & 22.69 \\
\hline Azoto + Azospril spp. & 31.25 & 25.00 & 23.25 & 21.25 & 25.19 \\
\hline Average of Salinity & 29.38 & 25.00 & 22.00 & 19.38 & \\
\hline
\end{tabular}

Table (4): Effect of soil salinity and application of promoting Rhizobacteria (PGPR) on number of branches of tomato plant in 2017 and 2018 seasons.

a) The first growing season (2017)

\begin{tabular}{lcccc}
\hline \multicolumn{1}{c}{$\begin{array}{c}\text { Rhizobacteria } \\
\text { treatment }\end{array}$} & \multicolumn{3}{c}{ Soil salinity* $\left(\mathbf{d S m}^{-1}\right)$} & $\begin{array}{c}\text { Average of } \\
\text { rhizobacteria }\end{array}$ \\
\cline { 2 - 4 } & $\mathbf{6 . 6}$ & $\mathbf{5 . 8}$ & $\mathbf{4 . 4}$ & \\
\hline Control & 8.50 & 11.25 & 11.25 & 10.33 \\
Azosprillum spp. & 10.25 & 11.50 & 11.75 & 11.167 \\
Azootobacter spp. & 10.75 & 12.00 & 11.75 & 11.50 \\
Azoto+Azospril spp. & 10.25 & 11.25 & 11.50 & 11.00 \\
Average of Salinity & 9.938 & 11.50 & 11.56 & \\
\hline
\end{tabular}

LSD at $1 \%$ for salinity means $=1.09$

Interaction means effects were NS 
SINAI Journal of Applied Sciences (ISSN: 2314-6079) Vol. (8) Is. (2), Aug. 2019

b) The second growing season (2018)

\begin{tabular}{lccccc}
\hline \multicolumn{1}{c}{$\begin{array}{c}\text { Rhizobacteria } \\
\text { treatment }\end{array}$} & \multicolumn{4}{c}{ Soil salinity* $\left(\mathbf{d S m}^{-\mathbf{1}}\right)$} & $\begin{array}{c}\text { Average of } \\
\text { rhizobacteria }\end{array}$ \\
\cline { 2 - 6 } & $\mathbf{0 . 3}$ & $\mathbf{1 . 4}$ & $\mathbf{1 . 9}$ & $\mathbf{3 . 6}$ & 15.56 \\
\hline Control & 19.00 & 17.50 & 14.25 & 11.50 & 16.50 \\
Azoto+Azospril spp. & 20.00 & 18.00 & 15.00 & 13.00 & \\
Average of Salinity & 19.50 & 17.75 & 14.63 & 12.25 & \\
\hline LSD at 1\% for salinity means =1.48 & LSD at 1\% for Rhizobacteria means = 0.77 \\
Interaction means effects were NS & * Application of PGPR to soil was at 10 days after transplanting.
\end{tabular}

\section{Chlorophyll content in tomato leaves}

Results in Table 5 indicate that salinity treatments did not affect total chlorophyll (a $+b)$ content in the first season, while it affected this character in the second one, whereas, salinity levels decreased total chlorophyll in tomato leaves and the decrement reached 9.8, 13.04 and 17.77\% for $1.4,1.9$ and $3.6 \mathrm{dSm}^{-1}$, respectively as compared to the low levels of $0.3 \mathrm{dSm}^{-1}$, especially in the second growing season. On the other side, addition of plant growth promoting rhizobacteria to tomato plants increased total chlorophyll significantly in the second growing season, whereas, this increment reached $5.78 \%$ compared to un treated plants with the same PGPR, while this character did not effected in the first season.

The interaction between plant growth promoting rhizobacteria and the levels of $0.3,1.4,1.9$ and $3.6 \mathrm{dSm}^{-1}$ indicated significantly decrease in total chlorophyll in tomato leaves in the second growing season, whereas, the decrement increased with the increment of salinity level as it reached 10.92, 15.66 and $19.08 \%$ for 1.4 , 1.9 and $3.6 \mathrm{dS} \mathrm{m}^{-1}$ of soil salinity compared with the level of $0.3 \mathrm{dSm}^{-1}$. It could be noticed that plants growing in low levels of salinity were affected significantly by PGPR more than plants grown in high levels of saline soil, especially, in the second growing season.
As shown in Table 5a the interaction between high levels of salinity (6.6 and 5.8 $\mathrm{dSm}^{-1}$ ) and each of Azotobacter and Azosprillium increased total chlorophyll in tomato leaves significantly compared to the untreated leaves with PGPR, where, the increment reached about 7.45 and $1.8 \%$ for the two PGPRs, respectively.

\section{Shoot dry matter per plant at harvest}

Results presented in Table 6 show that shoots dry matter/per plant was affected significantly by plant growth promoting rhizobacteria and salinity treatments. Tomato plants when exposed to different forms of rhizobacteria in soil improved its growth, where, it increased dry matter by 7.92, 23.01 and $29.42 \%$ for all Rhizobacterial forms compared to the untreated one (control) in the first season. However, it reached $11.82 \%$ compared to the control in the second growing season. On the other hand, salinity treatments affected significantly the dry matter per plant, whereas, dry matter decreased when salinity level increased in the two growing seasons. The decrement reached 2.89 and $12,88 \%$ for 4.4 and $5.8 \% \mathrm{dSm}^{-1}$ compared to $6.6 \mathrm{dSm}^{-1}$, respectively, in the first season, but in the second growing season, it reached $13.25,16.05$ and $6.65 \%$ for $0.3,1.4$ and $1.9 \mathrm{dSm}^{-1}$ compared to the high level of salinity $\left(3.6 \mathrm{dSm}^{-1}\right)$ in the second growing season. 
Table (5): Effect of soil salinity and application of promoting rhizobacteria (PGPR) on total chlorophyll content of tomato leaves in 2017 and 2018 seasons.

a) The first growing season (2017)

\begin{tabular}{lcccc}
\hline \multicolumn{1}{c}{$\begin{array}{c}\text { Rhizobacteria } \\
\text { treatment }\end{array}$} & \multicolumn{3}{c}{ Soil salinity* $\left.\mathbf{( d S m}^{-1}\right)$} & $\begin{array}{c}\text { Average of } \\
\text { rhizobacteria }\end{array}$ \\
\cline { 2 - 4 } & $\mathbf{6 . 6}$ & $\mathbf{5 . 8}$ & $\mathbf{4 . 4}$ & 39.15 \\
\hline Control & 37.83 & 39.53 & 40.10 & 39.00 \\
Azosprillum spp. & 39.75 & 40.25 & 37.00 & 39.08 \\
Azootobacter spp. & 40.65 & 37.43 & 39.18 & 38.93 \\
Azoto+Azospril spp. & 37.55 & 39.60 & 39.65 & \\
Average of Salinity & 38.94 & 39.60 & 38.98 & \\
\hline
\end{tabular}

Means of Salinity effects were NS

Means of Rhizobacteria effects were NS

LSD at $1 \%$ for Interaction $=2.02$

b) The second growing season (2018)

\begin{tabular}{lccccc}
\hline \multicolumn{1}{c}{$\begin{array}{c}\text { Rhizobacteria } \\
\text { treatment }\end{array}$} & \multicolumn{3}{c}{ Soil salinity* $\left(\mathbf{d S m}^{-1}\right)$} & $\begin{array}{c}\text { Average of } \\
\text { rhizobacteria }\end{array}$ \\
\cline { 2 - 5 } & $\mathbf{0 . 3}$ & $\mathbf{1 . 4}$ & $\mathbf{1 . 9}$ & $\mathbf{3 . 6}$ & \\
\hline Control & 40.81 & 37.62 & 36.69 & 34.16 & 37.39 \\
Azoto + Azospril spp. & 44.48 & 39.32 & 37.51 & 35.99 & 39.39 \\
Average of Salinity & 42.65 & 38.47 & 37.09 & 35.07 & \\
\hline
\end{tabular}

LSD at $1 \%$ for salinity means $=0.88$

LSD at $1 \%$ for Rhizobacteria means $=0.62$

LSD at $1 \%$ for interaction means $=1.25$

* Application of PGPR to soil was at 10 days after transplanting.

Table (6): Effect of soil salinity and application of promoting rhizobacteria (PGPR) on shoots dry matter of tomato plant at harvest in 2017 and 2018 season.

a) The first growing season (2017)

\begin{tabular}{lcccc}
\hline \multicolumn{1}{c}{$\begin{array}{c}\text { Rhizobacteria } \\
\text { treatment }\end{array}$} & \multicolumn{3}{c}{ Soil salinity* $\left(\mathbf{d S m}^{-\mathbf{1}}\right)$} & $\begin{array}{c}\text { Average of } \\
\text { rhizobacteria }\end{array}$ \\
\cline { 2 - 4 } & $\mathbf{6 . 6}$ & $\mathbf{5 . 8}$ & $\mathbf{4 . 4}$ & 9.04 \\
\hline Control & 9.95 & 9,61 & 9.55 & 10.66 \\
Azosprillum spp. & 10.82 & 9.39 & 11.73 & 11.12 \\
Azootobacter spp. & 11.43 & 9.40 & 12.10 & 11.70 \\
Azoto+Azospril spp. & 12.12 & 10.90 & 12.19 & \\
Average of Salinity & 11.08 & 9.94 & 11.41 & \\
\hline
\end{tabular}

LSD at $1 \%$ for salinity means $=1.29$

Interaction means effects were NS 
b) The second growing season (2018)

\begin{tabular}{cccccc}
\hline $\begin{array}{c}\text { Rhizobacteria } \\
\text { treatment }\end{array}$ & \multicolumn{4}{c}{ Soil salinity* $\left(\mathbf{d S m}^{-\mathbf{1}}\right)$} & $\begin{array}{c}\text { Average of } \\
\text { rhizobacteria }\end{array}$ \\
\cline { 2 - 5 } Control & $\mathbf{0 . 3}$ & $\mathbf{1 . 4}$ & $\mathbf{1 . 9}$ & $\mathbf{3 . 6}$ & 9.47 \\
Azoto+Azospril spp. & 11.31 & 11.51 & 10.22 & 9.32 & 10.59 \\
Average of Salinity & 10.56 & 10.63 & 9.77 & 9.16 & \\
\hline
\end{tabular}

LSD at $1 \%$ for salinity means $=0.25$

LSD at $1 \%$ for Rhizobacteria means $=0.18$

LSD at $1 \%$ for Interaction means $=0.36$

* Application of PGPR to soil was at 10 days after transplanting.

Concerning the interaction between salinity and plant growth promoting rhizobacteria it could be noticed that the forms of rhizobacteria used improved tomato plant growth and hence increased dry matter, specially, at the level of 4.4 and $0.3 \mathrm{dSm}^{-1}$ in the two growing seasons, respectively compared to the control

The obtained results related to PGPR are agree with those observed by different authors (Quilambo, 2000; KoKalis- Burelle et al ., 2002; Liu et al., 2002; Wu et al., 2005; Dimkpa et al., 2009; Hayat et al., 2010) who found that the use of different forms of plant growth promoting rhizobacteria increased and enhanced plant dry matter directly or indirectly. Also, numerus studies by Lopez (1998) indicated that potassium concentration uptake in plant tissues reflexed on dry matter weight as the $\mathrm{Na}$ - salinity in the root media increases, as a consequence of competitive uptake processes and resulted in growth and yield reduction. In addition, Martinez and Cerda (1989) and Al-Rawahy et al. (1990) reported that the decrement in tomato plant dry matter as a result of salinity may be due to nitrate reductase activity in tomato leaves as well as the decrement in nitrogen uptake.

\section{Roots dry weight}

Results in Table 7 show significant effects for salinity levels and plant growth promoting rhizobacteria (PGPR) on roots dry weight. Roots dry weight increased as salinity decreased. At harvest, roots dry weigh increased significantly with the addition of PGPR to the soil after transplanting in the two growing seasons, whereas, the roots weight at harvest increased significantly by $33.9 \%$ compared to untreated soil with PGPR in 2017 growing season as well as all PGPR treatments developed roots having high weight (17.9, 16.8 and 20.0\%) for PGPR treatments, respectively in the first season. On the other side, soil salinity interacted significantly with plant growth promoting rhizobacteria and enhanced roots weight of tomato plants during the growth season, whereas, the PGPR improved root growth when soil having less salinity. The increment in roots dry weight as a result of the interactions between salinity and PGPR reached 35.14 and $25.54 \%$ in the first and the second growing seasons, specially at the salinity treatments of 4.4 and $0.3 \mathrm{dSm}^{-1}$, respectively.

The significant increases in root dry weight agree with those observed by KoKalis-Burelle et al. (2002) as well as with those observed by Maria-Saubidt $\boldsymbol{e t}$ al. (2002), Gupta et al. (2000), and FanXiao-Hui (2017) who reported that most formulation of plant growth promoting rhizobacteria improved plant biomass, root dry weight and number of true leaves of both tomato and other some plants such as 
wheat, maize, and pepper. Also, our results agree with those reported by Liu et al. (2002) and Quilambo (2000) who indicated that PGPR and mycorrhiza increased plant biomass production, specially, leaves and root growth. Also, Loper and Schroth (1986) explained that this improvement may be due to the enhancement of plant growth regulators. Also, chlorophyll content results are similar to that observed by Yasseen et al. (2011) and Abdel-Fattah et al. (2016) who reported that the enhancement was due to microorganisms such as yeast or mycorrhiza. The increases in dry weight of roots as a result of PGPR may be due to that PGPR can reduce the environmental stress such as salinity and protect plant against root pathogen as observed by Ruizlozano et al. (1996). Other results explained that the improving as a result of the role of mycorrhiza symbiosis complements the role of plant roots that acts an extension of the root system increasing the absorption surface and then nutrients are better utilized (Muchovej, 2004).

\section{Flowering and Fruiting}

\section{Number of flowers/plant}

Results in Table 8 show significant effects for salinity levels and plant growth promoting rhizobacteria (PGPR) on number of flowers per plant. The Higher salinity treatment decreased number of flowers compared to the lower treatments (5.8 and $4.4 \mathrm{dSm}^{-1}$ ) as shown in Table ( $8 \mathrm{a}$ and $\mathrm{b}$ ). The decrement in flower number as a result of increasing salinity level $\left(6.6 \mathrm{dSm}^{-1}\right)$ reached $15.75 \%$ compared to lower level of salinity $\left(4.4 \mathrm{dSm}^{-1}\right)$ in the first season. In the second growing season, the decrement in flowers number as a result of increasing salinity $\left(3.6 \mathrm{dSm}^{-1}\right)$ reached $37.27 \%$ compared to the lower level of salinity $(0.3$ $\left.\mathrm{dSm}^{-1}\right)$. On the other side, plant growth promoting rhizobacteria improved significantly this trait, whereas, number of flowers per plant increased by $7.6 \%$ as a result of using PGPR compared to the untreated plants in the second growing season. In the first season, the mixture of the two strains was more effective than each of them alone or the control.

The interaction between plant growth promoting rhizobacteria and salinity did not show a clear trend on flowers number per plant, specially, in the 2017 growing season, but in the second one it could be notice that PGPR with the low level of salinity $\left(0.3 \mathrm{dSm}^{-1}\right)$ increased number of flowers per plant compared to its same interaction with the high level of salinity (3.6 $\mathrm{dSm}^{-1}$ ), whereas ,the increments reached $55.00,36.66$ and $21.66 \%$ for 0.3 , 1.4 and $1.9 \mathrm{dSm}^{-1}$ compared to $3.6 \mathrm{dSm}^{-1}$.

\section{Fruits number per plant}

Results in table 9 show significant effects for salinity levels and plant growth promoting rhizobacteria (PGPR) on number of fruits at harvest. Higher salinity levels inhibit fruit number compared to the lower level of salinity. It could say that $6.6 \mathrm{dSm}^{-1}$ salinity decreased this character by $14.62 \%$ compared to $4.4 \mathrm{dSm}^{-1}$ (Table 9a) as well as the level of $0.3 \mathrm{dSm}^{-1}$ (Table 9b). The aforementioned results specially which concerned with the effect of plant growth promoting rhizobacteria agree with those observed by Yaseen et al. (2011) who reported that mycorrhiza affected flowering and fruiting processes and then reduced cropping time due to earlier cowpea flowering pods per plant.

\section{Nutrients Content in Tomato Plant}

Data presented in Tables 10, 11, 12 and 13 indicate that nitrogen percentage in plant samples did not show a considerable difference in the two growing seasons as a result of planting tomato seedling in soil having different levels of salinity and inoculated by plant growth promoting rhizobacteria. 
SINAI Journal of Applied Sciences (ISSN: 2314-6079) Vol. (8) Is. (2), Aug. 2019

Table (7): Effect of soil salinity and application of promoting rhizobacteria (PGPR) on dry weight of tomato plant roots $(g)$ in 2017 and 2018 seasons.

a) The first growing season (2017)

\begin{tabular}{lcccc}
\hline \multicolumn{1}{c}{$\begin{array}{c}\text { Rhizobacteria } \\
\text { treatment }\end{array}$} & \multicolumn{3}{c}{ Soil salinity* $\left(\mathbf{d S m}^{-\mathbf{1}}\right)$} & $\begin{array}{c}\text { Average of } \\
\text { rhizobacteria }\end{array}$ \\
\cline { 2 - 4 } & $\mathbf{6 . 6}$ & $\mathbf{5 . 8}$ & $\mathbf{4 . 4}$ & 3.40 \\
\hline Control & 3.30 & 3.41 & 3.50 & 4.01 \\
Azosprillum spp. & 3.74 & 3.85 & 4.44 & 3.97 \\
Azootobacter spp. & 3.57 & 3.82 & 4.52 & 4.08 \\
Azoto+ Azospril spp. & 3.68 & 3.88 & 4.73 & \\
Average of Salinity & 3.56 & 3.74 & 4.30 & \\
\hline
\end{tabular}

LSD at $1 \%$ for Salinity means $=0.29$

LSD at $1 \%$ for Rhizobacteria means $=0.35$

LSD at $1 \%$ for interaction means $=0.59$

b) The second growing season (2018)

\begin{tabular}{lccccc}
\hline \multicolumn{1}{c}{$\begin{array}{c}\text { Rhizobacteria } \\
\text { treatment }\end{array}$} & \multicolumn{4}{c}{ Soil salinity* $\left.\mathbf{d S m}^{-1}\right)$} & $\begin{array}{c}\text { Average of } \\
\text { rhizobacteria }\end{array}$ \\
\cline { 2 - 5 } & 0.3 & 1.4 & 1.9 & 3.6 & 4.56 \\
\hline Control & 5.99 & 4.89 & 3.96 & 3.41 & 6.11 \\
Azoto + Azospril spp. & 7.52 & 6.90 & 5.04 & 5.01 & \\
Average of Salinity & 6.76 & 5.89 & 4.50 & 4.21 & \\
\hline
\end{tabular}

LSD at $1 \%$ for Salinity means $=0.26$

LSD at $1 \%$ for Rhizobacteria means $=0.18$

LSD at $1 \%$ for interaction means $=0.37$

* Application of PGPR to soil was at 10 days after transplanting.

Table (8): Effect of soil salinity and application of promoting rhizobacteria (PGPR) on number of flowers per tomato plant in 2017 and 2018 seasons.

a) The first growing season (2017)

\begin{tabular}{ccccc}
\hline $\begin{array}{c}\text { Rhizobacteria } \\
\text { treatment }\end{array}$ & \multicolumn{3}{c}{ Soil salinity* $\left(\mathbf{d S m}^{-1}\right)$} & $\begin{array}{c}\text { Average of } \\
\text { rhizobacteria }\end{array}$ \\
\cline { 2 - 4 } & $\mathbf{6 . 6}$ & $\mathbf{5 . 8}$ & $\mathbf{4 . 4}$ & \\
\hline Control & 11.25 & 16.00 & 17.25 & 14.83 \\
Azosprillum spp. & 12.50 & 17.00 & 11.75 & 13.75 \\
Azootobacter spp. & 15.50 & 12.75 & 15.75 & 14.67 \\
Azoto+Azospril spp. & 13.00 & 14.75 & 17.25 & 15.00 \\
Average of Salinity & 13.06 & 15.13 & 15.50 & \\
\hline
\end{tabular}

LSD at $1 \%$ for salinity means $=1.66$

LSD at $1 \%$ for Rhizobacteria means $=1.04$

LSD at $1 \%$ for interaction means $=3.31$ 
b) The second growing season (2018)

\begin{tabular}{cccccc}
\hline $\begin{array}{c}\text { Rhizobacteria } \\
\text { treatment }\end{array}$ & \multicolumn{3}{c}{ Soil salinity* $\left(\mathbf{d S m}^{-1}\right)$} & $\begin{array}{c}\text { Average of } \\
\text { rhizobacteria }\end{array}$ \\
\cline { 2 - 5 } & $\mathbf{0 . 3}$ & $\mathbf{1 . 4}$ & $\mathbf{1 . 9}$ & $\mathbf{3 . 6}$ & 17.89 \\
\hline Control & 21.00 & 18.75 & 16.25 & 12.75 & 19.25 \\
Azoto+Azospril spp. & 23.25 & 20.50 & 18.25 & 15.00 & \\
Average of Salinity & 22.13 & 19.63 & 17.25 & 13.88 & \\
\hline
\end{tabular}

LSD at $1 \%$ for Salinity means $=0.83$

LSD at $1 \%$ for Rhizobacteria means $=0.59$

Interaction means effects were NS

* Application of PGPR to soil was at 10 days after transplanting.

Table (9): Effect of soil salinity and application of plant growth promoting rhizobacteria (PGPR) on number of fruits per tomato plant at harvest in 2017 and 2018 seasons.

a) The first growing season (2017)

\begin{tabular}{ccccc}
\hline $\begin{array}{c}\text { Rhizobacteria } \\
\text { treatment }\end{array}$ & \multicolumn{3}{c}{ Soil salinity $\left(\mathbf{d S ~}^{-\mathbf{1}}\right)$} & $\begin{array}{c}\text { Average of } \\
\text { rhizobacteria }\end{array}$ \\
\cline { 2 - 4 } & $\mathbf{6 . 6}$ & $\mathbf{5 . 8}$ & $\mathbf{4 . 4}$ & \\
\hline Control & 8.50 & 11.25 & 11.25 & 10.33 \\
Azosprillum spp. & 10.25 & 11.50 & 11.75 & 11.17 \\
Azootobacter spp. & 10.75 & 12.00 & 11.75 & 11.50 \\
Azoto+ Azospril spp. & 10.25 & 11.25 & 11.50 & 11.00 \\
Average of Salinity & 9.94 & 11.50 & 11.63 & \\
\hline
\end{tabular}

LSD at $1 \%$ for salinity means $=1.09$

LSD at $1 \%$ for Rhizobacteria means $=0.78$

Interaction means effects were NS

b) The second growing season (2018)

\begin{tabular}{cccccc}
\hline $\begin{array}{c}\text { Rhizo bacteria } \\
\text { treatment }\end{array}$ & \multicolumn{4}{c}{ Soil salinity $\left(\mathbf{d S ~ \mathbf { ~ m } ^ { \mathbf { - 1 } } )}\right.$} & $\begin{array}{c}\text { Average of } \\
\text { rhizobacteria }\end{array}$ \\
\cline { 2 - 5 } & $\mathbf{0 . 3}$ & $\mathbf{1 . 4}$ & $\mathbf{1 . 9}$ & $\mathbf{3 . 6}$ & 13.56 \\
Control & 15.50 & 13.75 & 12.50 & 12.50 & 15.06 \\
Azoto+Azospril spp. & 17.25 & 15.25 & 14.75 & 13.00 & \\
Average of Salinity & 16.38 & 14.50 & 13.63 & 12.75 & \\
\hline
\end{tabular}

LSD at $1 \%$ for salinity means $=2.33$

LSD at $1 \%$ for Rhizobacteria means $=1.56$

Interaction means effects were NS

* Application of PGPR to soil was at 10 days after transplanting. 
SINAI Journal of Applied Sciences (ISSN: 2314-6079) Vol. (8) Is. (2), Aug. 2019

Table (10): Effect of soil salinity and application of promoting rhizobacteria (PGPR) on nitrogen percentage $(\%)$ in tomato dry matter plant sample at harvest in 2017 and 2018 seasons.

a) The first growing season (2017)

\begin{tabular}{ccccc}
\hline Rhizobacteria & \multicolumn{3}{c}{ Soil salinity* $\left(\mathbf{d S m}^{-\mathbf{1}}\right)$} & $\begin{array}{c}\text { Average of } \\
\text { treatment }\end{array}$ \\
\cline { 2 - 4 } rhizobacteria \\
\hline Control & $\mathbf{6 . 6}$ & $\mathbf{5 . 8}$ & $\mathbf{4 . 4}$ & 2.39 \\
Azosprillum spp. & 2.58 & 2.25 & 2.33 & 2.28 \\
Azootobacter spp. & 2.30 & 2.20 & 2.33 & 2.32 \\
Azoto+ Azospril spp. & 2.30 & 2.33 & 2.33 & 2.28 \\
Average of Salinity & 2.35 & 2.25 & 2.22 & \\
\hline
\end{tabular}

Salinity means effects were NS

Rhizobacteria means effects were NS

Interaction means effects were NS

b) The second growing season (2018)

\begin{tabular}{cccccc}
\hline $\begin{array}{c}\text { Rhizobacteria } \\
\text { treatment }\end{array}$ & \multicolumn{4}{c}{ Soil salinity* $\left(\mathbf{d S m}^{-1}\right)$} & $\begin{array}{c}\text { Average of } \\
\text { rhizobacteria }\end{array}$ \\
\cline { 2 - 5 } & $\mathbf{0 . 3}$ & $\mathbf{1 . 4}$ & $\mathbf{1 . 9}$ & $\mathbf{3 . 6}$ & \\
\hline Control & 3.16 & 3.40 & 2.84 & 3.16 & 3.14 \\
Azoto+Azospril spp. & 3.68 & 3.53 & 2.74 & 3.11 & 3.27 \\
Average of Salinity & 3.42 & 3.47 & 2.79 & 3.14 & \\
\hline
\end{tabular}

LSD at $1 \%$ for salinity means $=0.43$

Rhizobacteria means effects were NS

Inter action means effects were NS

* Application of PGPR to soil was at 10 days after transplanting.

Table (11): Effect of soil salinity and application of promoting rhizobacteria (PGPR) on phosphorus concentration $(\mathrm{g} / \mathrm{kg})$ in tomato plant dry matter at harvest in 2017 and 2018 seasons.

a) The first growing season (2017)

\begin{tabular}{ccccc}
\hline $\begin{array}{c}\text { Rhizobacteria } \\
\text { treatment }\end{array}$ & \multicolumn{3}{c}{ Soil salinity* $\left(\mathbf{d S m}^{-1}\right)$} & $\begin{array}{c}\text { Average of } \\
\text { rhizobacteria }\end{array}$ \\
\cline { 2 - 4 } & $\mathbf{6 . 6}$ & $\mathbf{5 . 8}$ & $\mathbf{4 . 4}$ & 6.28 \\
Control & 6.20 & 6.28 & 6.35 & 6.05 \\
Azosprillum spp. & 5.73 & 6.20 & 6.23 & 6.16 \\
Azootobacter spp. & 6.13 & 6.68 & 5.68 & 6.14 \\
Azoto+Azospril spp. & 5.75 & 6.90 & 5.78 & \\
Average of Salinity & 5.95 & 6.51 & 6.01 & \\
\hline
\end{tabular}

LSD at $1 \%$ for salinity means $=0.48$

Rhizobacteria means effects were NS

Interaction means effects were NS 
b) The second growing season (2018)

\begin{tabular}{cccccc}
\hline $\begin{array}{c}\text { Rhizobacteria } \\
\text { treatment }\end{array}$ & \multicolumn{3}{c}{ Soil salinity* $\left(\mathbf{d S m}^{-1}\right)$} & & $\begin{array}{c}\text { Average of } \\
\text { rhizobacteria }\end{array}$ \\
\cline { 2 - 5 } & $\mathbf{0 . 3}$ & $\mathbf{1 . 4}$ & $\mathbf{1 . 9}$ & $\mathbf{3 . 6}$ & \\
\hline Control & 11.87 & 10.66 & 14.76 & 10.26 & 11.89 \\
Azoto+Azospril spp. & 12.19 & 12.19 & 16.56 & 10.99 & 12.98 \\
Average of Salinity & 12.03 & 11.43 & 15.66 & 10.62 & \\
\hline
\end{tabular}

LSD at $1 \%$ for salinity means $=1.58$

LSD at $1 \%$ for Rhizobacteria means $=1.08$

Interaction means effects were NS

* Application of PGPR to soil was at 10 days after transplanting.

Table (12): Effect of soil salinity and application of promoting rhizobacteria (PGPR) on Potassium concentration $(\mathrm{g} / \mathrm{kg})$ in tomato plant dry matter at harvest in 2017 and 2018 seasons.

a) The first growing season (2017)

\begin{tabular}{ccccc}
\hline Rhizobacteria & \multicolumn{3}{c}{ Soil salinity* $\left(\mathbf{d S m}^{-\mathbf{1}}\right)$} & $\begin{array}{c}\text { Average of } \\
\text { treatment }\end{array}$ \\
\cline { 2 - 4 } rhizobacteria \\
\hline Control & $\mathbf{6 . 6}$ & $\mathbf{5 . 8}$ & $\mathbf{4 . 4}$ & 23.15 \\
Azosprillum spp. & 24.78 & 22.65 & 22.03 & 22.92 \\
Azootobacter spp. & 23.46 & 23.03 & 22.28 & 24.63 \\
Azoto+ Azospril spp. & 25.84 & 25.22 & 22.84 & 23.78 \\
Average of Salinity & 24.83 & 22.22 & 23.78 & \\
\hline
\end{tabular}

LSD at $1 \%$ for salinity means $=1.74$

Rhizobacteria means was NS

Interaction means effects were NS

b) The second growing season (2018)

\begin{tabular}{cccccc}
\hline $\begin{array}{c}\text { Rhizobacteria } \\
\text { treatment }\end{array}$ & $\mathbf{0 . 3}$ & $\mathbf{1 . 4}$ & $\mathbf{1 . 9}$ & $\mathbf{3 . 6}$ & $\begin{array}{c}\text { Average of } \\
\text { rhizobacteria }\end{array}$ \\
\cline { 2 - 5 } & 25.78 & 26.09 & 25.60 & 24.91 & 25.59 \\
Control & 28.53 & 27.72 & 27.41 & 26.09 & 27.44 \\
Azoto+Azospril spp. & Azolinity* $\left.\mathbf{d S m}^{-1}\right)$ & \\
Average of Salinity & 27.16 & 26.91 & 26.50 & 25.50 & \\
\hline
\end{tabular}

Salinity means effects were N.S.

LSD at $1 \%$ for Rhizobacteria means $=1.40$

Interaction means effects were N.S.

* Application of PGPR to soil was at 10 days after transplanting. 
SINAI Journal of Applied Sciences (ISSN: 2314-6079) Vol. (8) Is. (2), Aug. 2019

Table (13): Effect of soil salinity and application of plant growth promoting rhizobacteria (PGPR) on sodium content $(\mathrm{g} / \mathrm{kg})$ in tomato plant dry matter at harvest after 10 days from PGPR treatment during 2017 and 2018 seasons

a) The first growing season (2017)

\begin{tabular}{ccccc}
\hline \multirow{2}{*}{$\begin{array}{c}\text { Rhizobacteria } \\
\text { treatment }\end{array}$} & \multicolumn{3}{c}{ Soil salinity $\left(\mathbf{d S ~ \mathbf { ~ m } ^ { \mathbf { - 1 } } )}\right.$} & $\begin{array}{c}\text { Average of } \\
\text { rhizobacteria }\end{array}$ \\
\cline { 2 - 4 } & $\mathbf{6 . 6}$ & $\mathbf{5 . 8}$ & $\mathbf{4 . 4}$ & 21.19 \\
control & 21.47 & 22.65 & 19.47 & 19.84 \\
Azosprillum spp. & 22.59 & 16.20 & 20.72 & 19.73 \\
Azootobacter spp. & 22.72 & 15.39 & 21.09 & 20.86 \\
Azoto + Azospril spp. & 22.84 & 18.15 & 21.59 & \\
Average of Salinity & 22.84 & 18.10 & 20.71 & \\
\hline
\end{tabular}

LSD at $1 \%$ for salinity means $=4.19$

Rhizobacteria means effects were NS

LSD at $1 \%$ for Interaction means $=3.95$

b) The second growing season (2018)

\begin{tabular}{cccccc}
\hline $\begin{array}{c}\text { Rhizobacteria } \\
\text { treatment }\end{array}$ & \multicolumn{4}{c}{ Soil salinity $\left(\mathbf{d S ~ m}^{-1}\right)$} & $\begin{array}{c}\text { Average of } \\
\text { rhizobacteria }\end{array}$ \\
\cline { 2 - 5 } & 0.3 & 1.4 & 1.9 & 3.6 & 19.63 \\
Control & 26.91 & 15.27 & 17.39 & 18.97 & 17.84 \\
(Azoto+Azospril spp. & 25.72 & 13.52 & 14.46 & 17.65 & \\
Average of Salinity & 26.31 & 14.40 & 15.92 & 18.31 & \\
\hline
\end{tabular}

LSD at $1 \%$ for salinity means $=2.06$

LSD at $1 \%$ for Rhizobacteria means $=1.46$

Inter action means effects were NS

*Application of PGPR to soil was at 10 days after transplanting.

Concerning the effect of salinity on phosphorus, potassium and sodium, it could be noticed that phosphorus and potassium contents were reduced with higher levels of salinity as indicated from Tables 11 and 12 and these results are true in the two growing seasons. With regard to content of phosphorus, it could be notice that rhizobacteria enhanced phosphorus percentage in tomato dry matter/plant, especially in the second season, whereas, the increment reached $9.16 \%$ compared to the control, while, potassium decrement reached $6.74 \%$, whereas potassium and sodium (Table 13) followed the opposite trend of phosphorus. Also, it could be notice that rhizobacteria increment reached $10.09 \%$ compared to the control. In the second season, the trend in the first season did not show a clear trend.

The obtained results were not in agreement with those observed by Voogt (1987), but are in harmony with those observed by Adams and Ho (1995) who mentioned that increasing salinity reduced $\mathrm{K}^{+}$uptake. The literature sited on phosphorus agree with those observed in our study, whereas, Dobereiner (1997) showed that rhizobacteria can fix and solubilizing phosphorus, and have been 
alternative to mineral fertilizer to increase yield and plant growth (De Freitas et al., 1997; Canbolate et al., 2006).

\section{Nitrogen Atom Excess Percentage in Plant Sample}

Results in Table 14 indicate that, in concern with salinity role in labeled nitrogen, it could be notice that $\mathrm{N}^{15}$ uptake by tomato plant increased significantly as salinity increased in soil, whereas, it reached 5.51 and $4.34 \%$ for 6.6 and 5.8 $\mathrm{dSm}^{-1}$, respectively compared to $4.4 \mathrm{dm}^{-1}$ in the 2017 season. However, in the 2018 season it reached $8.84,12.7 \%$ for 0.3 and $1.4 \mathrm{dSm}^{-1}$ compared to the high level of salinity $\left(3.6 \mathrm{dS} \mathrm{m}^{-1}\right)$ indicating un opposite trend relating the first growing season.

Concerning nitrogen $\mathrm{N}^{15}$ atom excess, it could be notice from Table (14 a and b) that the application of plant growth promoting rhizobacteria in all forms improved nitrogen labeled atom excess in tomato plants.

The enhancing in $\mathrm{N}^{15}$ uptake could be measured and it reached 18.67 and $11.83 \%$ for the application of rhizobacteria in the first and the second growing seasons, respectively compared to the soil without inoculation.

The interaction between rhizobacteria and soil salinity on nitrogen labeled showed a significant increment at all salinity levels and all rhizobacteria forms in 2017 season. The observed results are in agreement with those mentioned by Gupta et al. (2000), Maria et al. (2002) and Wu et al. (2005) who reported that use of Arbuscular mycorrhizal fungi (AMF) and soil Azospirillum improved $\mathrm{N}$ content and $\mathrm{N}$ concentration in plant tissues as a result of nitrogen absorbed easily by roots. Also, Fan-Xiao-Hui et al. (2017) reported that using PGPR improved $\mathrm{N}$ uptake and increased $\mathrm{N}$ uptake in shoots for all treatments in calcareous soils.

\section{Total Nitrogen Yield (g)/plant}

Total $\mathrm{N}$ yield per tomato plant was determined by multiplying nitrogen percent in plant sample of tomato at harvest time by dry matter per plant and the data are presented in Table 15. Total $\mathrm{N}$ yield of tomato plant as a result of planting tomato in relatively salinity ranged between 0.3 to $6.6 \mathrm{dSm}^{-1}$ during the two growing seasons as well as inoculation of plant media by plant growth promoting rhizobacteria in different forms was increased significantly by the rhizobacteria treatment in both growing seasons.

The increment in total $\mathrm{N}$ yield could be noticed as a result of the increment in total dry matter per plant at the end of growth season. The increment reached 15.52 and $12.93 \%$ compared to the uninoculated soil by plant growth promoting rhizobacteria in the first season, but it reached $16.39 \%$ in the second one. It could be noticed that the mixture between the two strains of PGPR was more effective on total dry matter and reflected on total nitrogen yield at harvest. On the other side, saline soil did not show reduction in total $\mathrm{N}$ yield as salinity increased, this may be as a result of the effect of salinity on total dry matter of plant as mentioned before and did not related with nitrogen percentage in plant sample which was not affected significantly in the two growing seasons.

\section{Nitrogen Derived from Fertilizer (Ndff \%)}

In this respect, it could be noticed that nitrogen derived from ammonium sulphate by tomato plants were improved significantly with treating soil by rhizobacteria through the two growing seasons, whereas, the increment reached 11.67, 10.65 and 18.65 for the first and second strains and their mixture in the 2017 growing season, and reached $11.46 \%$ for the mixture of both strains in the second growing season as compared to the control 
SINAI Journal of Applied Sciences (ISSN: 2314-6079) Vol. (8) Is. (2), Aug. 2019

Table (14): Effect of soil salinity and application of promoting rhizobacteria (PGPR) on $\mathrm{N}^{15}$ atom excess\% in dry matter in tomato dry matter plant sample after harvest at harvest in 2017 and 2018 seasons.

a) The first growing season (2017)

\begin{tabular}{|c|c|c|c|c|}
\hline \multirow{2}{*}{$\begin{array}{c}\text { Rhizobacteria } \\
\text { treatment }\end{array}$} & \multicolumn{3}{|c|}{ Soil salinity* $\left(\mathrm{dSm}^{-1}\right)$} & \multirow{2}{*}{$\begin{array}{c}\text { Average of } \\
\text { rhizobacteria }\end{array}$} \\
\hline & 6.6 & 5.8 & 4.4 & \\
\hline Control & 0.978 & 0.835 & 0.839 & 0.884 \\
\hline Azosprillum spp. & 0.971 & 1.035 & 0.957 & 0.988 \\
\hline Azootobacter spp. & 0.963 & 1.044 & 0.928 & 0.979 \\
\hline Azoto + Azospril spp. & 1.071 & 1.025 & 1.051 & 1.049 \\
\hline Average of Salinity & 0.996 & 0.985 & 0.944 & \\
\hline
\end{tabular}

LSD at $1 \%$ for salinity means $=0.04$

LSD at $1 \%$ for Rhizobacteria means $=0.08$

$\mathrm{LSD}$ at $1 \%$ for Interaction means $=0.1$

b) The second growing season (2018)

\begin{tabular}{cccccc}
\hline $\begin{array}{c}\text { Rhizobacteria } \\
\text { treatment }\end{array}$ & \multicolumn{3}{c}{ Soil salinity* $\left.\mathbf{( d S m}^{-1}\right)$} & $\begin{array}{c}\text { Average of } \\
\text { rhizobacteria }\end{array}$ \\
\cline { 2 - 5 } & 0.3 & 1.4 & 1.9 & 3.6 & 0.786 \\
Control & 0.814 & 0.898 & 0.693 & 0.749 & 0.879 \\
Azoto+Azospril spp. & 0.935 & 0.912 & 0.812 & 0.857 & \\
Average of Salinity & 0.874 & 0.905 & 0.753 & 0.803 & \\
\hline
\end{tabular}

LSD at $1 \%$ for salinity means $=0.07$

LSD at $1 \%$ for Rhizobacteria means $=0.05$

Inter action means effects were NS

* Application of PGPR to soil was at 10 days after transplanting.

Table (15): Effect of soil salinity and application of promoting rhizobacteria (PGPR) on total nitrogen yield (g/plant) of tomato plant at harvest in 2017 and 2018 seasons.

a) The first growing season (2017)

\begin{tabular}{ccccc}
\hline Rhizobacteria & \multicolumn{3}{c}{ Soil salinity* $\left(\mathbf{d S m}^{-1}\right)$} & $\begin{array}{c}\text { Average of } \\
\text { treatment }\end{array}$ \\
\cline { 2 - 4 } rhizobacteria \\
\hline Control & $\mathbf{6 . 6}$ & $\mathbf{5 . 8}$ & $\mathbf{4 . 4}$ & 0.232 \\
Azosprillum spp. & 0.258 & 0.217 & 0.223 & 0.243 \\
Azootobacter spp. & 0.267 & 0.205 & 0.275 & 0.262 \\
Azoto+Azospril spp. & 0.285 & 0.233 & 0.285 & 0.268 \\
Average of Salinity & 0.264 & 0.245 & 0.273 & \\
\hline
\end{tabular}

LSD at $1 \%$ for salinity means $=0.042$

LSD at $1 \%$ for Rhizobacteria means $=0.034$

Inter action means effects were NS 
b) The second growing season (2018)

\begin{tabular}{cccccc}
\hline Rhizobacteria & \multicolumn{4}{c}{ Soil salinity* $\left(\mathbf{d S m}^{-1}\right)$} & $\begin{array}{c}\text { Average of } \\
\text { rhizobacteria }\end{array}$ \\
\cline { 2 - 5 } & $\mathbf{0 . 3}$ & $\mathbf{1 . 4}$ & $\mathbf{1 . 9}$ & $\mathbf{3 . 6}$ & 0.299 \\
treatment & 0.310 & 0.330 & 0.272 & 0.285 & 0.348 \\
Control & 0.415 & 0.407 & 0.280 & 0.290 & \\
Azoto + Azospril spp. & 0.362 & 0.369 & 0.276 & 0.288 & \\
\hline Average of Salinity & 0.276
\end{tabular}

LSD at $1 \%$ for salinity means $=0.053$

LSD at $1 \%$ for Rhizobacteria means $=0.037$

LSD at $1 \%$ for Interaction means $=0.056$

* Application of PGPR to soil was at 10 days after transplanting.

treatment in the two seasons. As a result of salinity, nitrogen derived from fertilizer absorption increased in the first seasons but followed the opposite trend in the second season. The interaction between salinity levels and the application of rhizobacteria indicated that nitrogen derived from fertilizer was improved in high level of the saline soil in the first growing season, whereas, it was the best compared to the control treatments. The increments in nitrogen derived from fertilizer should be consider a result of the increment in atom excess in plant sample, which were higher for these treatments as shown in Table 16 a and $b$.

\section{Fertilizer Nitrogen Yield (FNY) (g)}

Regarding salinity and its effect on fertilizer nitrogen yield, it could say that salinity in soil reduced the nitrogen absorbed by plant from the fertilizer applied, specially, in the second growing season, where, the decrements due to salinity were 35.63 and $28.13 \%$ for 1.9 and $3.6 \mathrm{dSm}^{-1}$, respectively as compared to 0.3 $\mathrm{dSm}^{-1}$ (Table 17b). Plant growth promoting rhizobacteria in different forms increased fertilizer nitrogen yield (FNY) in tomato plants significantly in both growing seasons, whereas the increment in this trait reached $36.89,24.27$ and $15.53 \%$ compared to the control in the first growing season. In the second season, the increment reached $32.48 \%$ compared to the chick treatment (Table 17).
The changes in fertilizer (Nitrogen) yield (g) could be due the changes in nitrogen derived from fertilizer (Ndff \%) and their difference in its atom excess percentages as well as its reflection resulted from the difference in total $\mathrm{N}$ yield and total dry matter per plant as its change due to the experiment treatments (salinity and rhizobacteria).

\section{N- Utilized Percentage (Fertilizer Use Efficiency)}

$\mathrm{N}$-Utilized percentage was determined as a percentage for nitrogen absorbed by tomato plant from the applied ammonium sulphate (fertilizer N-utilized) and the results are recorded in Table 18. In concern with salinity effect on $\mathrm{N}$ - utilized, it could be saying that higher salinity reduced the utilized $\mathrm{N}$ from the fertilizer applied, as shown in Table 18-b, where, the reduction reached 28.12 and 35.94 for 3.6 and 1.9 $\mathrm{dSm}^{-1}$ compared to $0.3 \mathrm{dSm}^{-1}$, respectively. Application of rhizobacteria in different forms increased significantly nitrogen use efficiency as expressed in the term of $\mathrm{N}$ utilized. The increments in N-utilized percentage were $35.94,23.45$ and $15.30 \%$ for the mixture of the strains 2 and 1 , respectively; it reached $32.62 \%$ for the mixture as compared to the chick treatment as shown in Table (18 b).

The interaction between salinity and rhizobacteria used showed significant effect as a result of salinity at 0.3 and 1.4 with the mixture of rhizobacteria used increased 
SINAI Journal of Applied Sciences (ISSN: 2314-6079) Vol. (8) Is. (2), Aug. 2019

Table (16): Effect of soil salinity and application of promoting rhizobacteria (PGPR) on Nitrogen derived from fertilizer percentage (\%) for tomato plants after harvest in 2017 and 2018 seasons.

a) The first growing season (2017)

\begin{tabular}{ccccc}
\hline Rhizobacteria & \multicolumn{3}{c}{ Soil salinity* $\left(\mathbf{d S m}^{-1}\right)$} & $\begin{array}{c}\text { Average of } \\
\text { treatment }\end{array}$ \\
\cline { 2 - 4 } rhizobacteria \\
\hline Control & $\mathbf{6 . 6}$ & $\mathbf{5 . 8}$ & $\mathbf{4 . 4}$ & 44.218 \\
Azosprillum spp. & 48.925 & 41.755 & 41.975 & 49.380 \\
Azootobacter spp. & 48.548 & 51.730 & 47.862 & 48.927 \\
Azoto+ Azospril spp. & 53.575 & 52.200 & 46.418 & 52.465 \\
Average of Salinity & 49.803 & 51.255 & 52.565 & \\
\hline A & 49.235 & 47.205 & \\
\hline
\end{tabular}

LSD at $1 \%$ for salinity means $=2.03$

LSD at $1 \%$ for Rhizobacteria means $=4.30$

LSD at $1 \%$ for Interaction means $=7.44$

b) The second growing season (2018)

\begin{tabular}{|c|c|c|c|c|c|}
\hline \multirow{2}{*}{$\begin{array}{c}\text { Rhizobacteria } \\
\text { treatment }\end{array}$} & \multicolumn{4}{|c|}{ Soil salinity* $\left(\mathrm{dSm}^{-1}\right)$} & \multirow{2}{*}{$\begin{array}{c}\text { Average of } \\
\text { rhizobacteria }\end{array}$} \\
\hline & 0.3 & 1.4 & 1.9 & 3.6 & \\
\hline Control & 40.695 & 44.912 & 34.675 & 37.435 & 39.429 \\
\hline Azoto + Azospril spp. & 46.727 & 45.608 & 40.622 & 42.828 & 43.946 \\
\hline Average of Salinity & 43.711 & 45.260 & 37.649 & 40.131 & \\
\hline
\end{tabular}

LSD at $1 \%$ for salinity means $=3.51$

LSD at $1 \%$ for Rhizobacteria means $=2.48$

Interaction means effects were NS

* Application of PGPR to soil was at 10 days after transplanting.

Table (17): Effect of soil salinity and application of promoting rhizobacteria (PGPR) on Fertilizer nitrogen yield (g/plant) for tomato plants at harvest in 2017 and 2018 seasons.

a) The first growing season (2017)

\begin{tabular}{ccccc}
\hline Rhizobacteria & \multicolumn{3}{c}{ Soil salinity* $\left(\mathbf{d S m}^{-1}\right)$} & $\begin{array}{c}\text { Average of } \\
\text { treatment }\end{array}$ \\
\cline { 2 - 4 } rhizobacteria
\end{tabular}

LSD at $1 \%$ for salinity means $=0.025$

$\mathrm{LSD}$ at $1 \%$ for Rhizobacteria means $=0.031$

Inter action means effects were NS 
b) The second growing season (2018)

\begin{tabular}{cccccc}
\hline Rhizobacteria & \multicolumn{4}{c}{ Soil salinity* $\left(\mathbf{d S m}^{-1}\right)$} & $\begin{array}{c}\text { Average of } \\
\text { treatment }\end{array}$ \\
\cline { 2 - 6 } rhizobacteria
\end{tabular}

LSD at $1 \%$ for salinity means $=0.023$

LSD at $1 \%$ for Rhizobacteria means $=0.016$

LSD at $1 \%$ for interaction means $=0.024$

* Application of PGPR to soil was at 10 days after transplanting.

Table (18): Effect of soil salinity and application of promoting rhizobacteria (PGPR) on nitrogen utilized (\%) for tomato plants after harvest in 2017 and 2018 seasons.

a) The first growing season (2017)

\begin{tabular}{lcccc}
\hline \multirow{2}{*}{$\begin{array}{c}\text { Rhizobacteria } \\
\text { treatment }\end{array}$} & $\mathbf{6 . 6}$ & $\mathbf{5 . 8}$ & $\mathbf{4 . 4}$ & $\begin{array}{c}\text { Soil salinity* }\left(\mathbf{d S m}^{-1}\right) \\
\text { rhizobacteria }\end{array}$ \\
\cline { 2 - 4 } & 27.945 & 20.220 & 20.778 & 22.981 \\
\hline Control & 26.722 & 23.497 & 29.275 & 26.498 \\
Azosprillum spp. & 28.665 & 26.997 & 29.445 & 28.369 \\
Azootobacter spp. & 34.003 & 27.887 & 31.833 & 31.241 \\
Azoto+ Azospril spp. & 29.334 & 24.651 & 27.833 & \\
Average of Salinity & & &
\end{tabular}

LSD at $1 \%$ for salinity means $=5.52$

LSD at $1 \%$ for Rhizobacteria means $=6.77$

Interaction means effects were N.S.

b) The second growing season (2018)

\begin{tabular}{cccccc}
\hline $\begin{array}{c}\text { Rhizobacteria } \\
\text { treatment }\end{array}$ & $\mathbf{0 . 3}$ & $\mathbf{1 . 4}$ & $\mathbf{1 . 9}$ & $\mathbf{3 . 6}$ & $\begin{array}{c}\text { Average of } \\
\text { rhizobacteria }\end{array}$ \\
\cline { 2 - 5 } & 27.777 & 32.220 & 20.555 & 23.330 & 25.917 \\
Control & 43.330 & 41.667 & 25.000 & 27.778 & 34.444 \\
Azoto+Azospril spp. & 35.554 & 36.944 & 22.777 & 25.554 & \\
Average of Salinity & $\left.35 \mathbf{A S m}^{-1}\right)$ & \\
\hline
\end{tabular}

LSD at $1 \%$ for salinity means $=5.121$

LSD at $1 \%$ for Rhizobacteria means $=3.621$

LSD at $1 \%$ for interaction means $=5.321$

* Application of PGPR to soil was at 10 days after transplanting. 
nitrogen use efficiency significantly in tomato plants as presented in Table $18 \mathrm{~b}$, where, the differences reached $56.0 \%$ and $50.0 \%$ for the two levels of salinity, respectively, as compared to the control $\left(0.3 \mathrm{dSm}^{-1}\right)$.

\section{REFRENCES}

Abdel-Fattah, G.M.; Rabie, G.H.; Lamis, D.S.H. and Rabab, A.M. (2016). The impact of the arbuscular mycorrhizal fungi on growth and physiological parameters of cowpea plants grown under salt stress conditions. Int. J. Appl. Sci. Biotechnol., 4(3): 372-379.

Adams, P. and Ho, L.C. (1995). Uptake and distribution of nutrients in relation to tomato fruit quality. Acta Hort., 41: 374-387.

Adesemoye, A.O.; Torbert, H.A. and Kloepper, J.W. (2009). Plant growthpromoting rhizobacteria allow reduced application rates of chemical fertilizers. Microb. Ecol., 58:921-929.

Ali, H.R.S.; Amar, U.; Khalid, R. and Ahmed, I. (2010). Soil beneficial bacteria and their role in plant growth promoting: a review. Ann. Microbiol., 60: 5798 .

Aloni, R.I.; Aloni, E.; Langhans, M. And Ullrich, C.I. (2006). Role of auxin in regulating Arabidopsis flower development. Planta., 223(2): 315-28.

Al-Rawahy, S.A.; Stroehlein, J.L. and Pessarakli, M. (1990). Effect of salt stress on dry matter production and nitrogen uptake by tomatoes, J. Plant Nutr., 13: 567-577.

Boddey, R.M. and Dobereiner, I. (1995). Nitrogen fixation associated with grasses and cereals: recent progress and perspectives for the future. Fert. Res., 42: $241-250$

Canbolat, M.Y.; Barik, K.K.; Cakmarci, R. and Sabin, F. (2006). Effects of mineral and biofertilizers on barley growth on compacted soil. Acta. Agric. Sci., 56:324-332.

Cotteine, A.; Verioo, M.; Kiekens, L.; Velghe, G. and Camerlynck, R. (1982). Chemical Analysis of Plant and Soils. Lab. Analytical Agrochemistry, State Univ., Ghent, Brussel-Belgium.

De Freitas, J.R.; Banerjee, M.R. and Germida, J.J. (1997). Phosphatesolubilizing rhizobacteria enhance the growth and yield but not phosphorus uptake of canola (Brassica napus). Biol. Fertile Soils, 36: 842-855

Dimkpa, C.; Tanja, W. and Folkard, A. (2009). Plant-rhizobacteria interactions alleviate abiotic stress conditions. Plant, Cell and Environ., 32 (12): 1633-1844.

Dobereiner, J. 1997. Biological nitrogen fixation in the tropics: social and economic contributions. Soil Biol. Biochem., 29: 771-774.

Fan-Xiao, H.; Zhang, S.; Mo, X.; LI, Y.; FUyu, Q. and LIUZhi, G. (2017). Effect of PGPR and N Source on plant growth and $\mathrm{N}, \mathrm{P}$ Uptake by tomato grown in calcareous soils. Pedosphere ISSN 1002-0160/CN 32-1315.

Fiedler, R. and Proksch, G. (1975). The determination of nitrogen- 15 by emission and mass spectrometry in biochemical analysis: A Rev., Anal Chim. Acta, 78: $1-62$.

Gupta, A.; Gopal, M. and Tilak, K.V. (2000). Mechanism of plant growth promotion by rhizobacteria. Indian $\mathrm{J}$. Exp. Biol., 38: 856-862.

IAEA (2001). Training course. Int. Atomic Energy Agency (IAEA) No. 14, Vienna, Austria.

Jones, J.B.; Wolf, B. and Mills, H.A. (1991). Plant Analysis Handbook. Appendix 3 and 4, pp. 195-203, MicroMacro Publishing, Inc., Athens-GA, USA. 
Kokalis-Burelle, N.; Vavrina, C.S.; Rossskopf, E.N. and Shelby, R.A. (2002). Field evaluation of plant growthpromoting rhizobacteria amended transplant mixes and soil solarization for tomato and pepper production in Florida. Plant Soil, 238: 257-266.

Krinsky, J.L. (1991). The Navy's Chlorofluorocarbon/Halon Program. Naval Eng. J., 103 (3): 8-296.

Liu, A.; Hamed, C.; Elmi, A.; Costa, C.; Ma, B. and Smith, D.L. (2002). Concentration of $\mathrm{K}, \mathrm{Ca}$ and $\mathrm{Mg}$ in maize colonized by Arbuscular Mycorrhizal fungi under field conditions. Can. J. Soil Sci., 82 (3): 271-278.

Loper, J.E. and Schroth, M.N. (1986). Influence of bacterial sources of indole3 -acetic acid on root elongation of sugar beet. Phytopathol., 76: 386-389.

Lopez, J.B. (1998). Etude des effects des ions sulfates dans la solution nutritive sur la croissance, la physiologie, la nutrition minerale et la productivite de la tomate de serre, These de doctorat, Univ. Laval, Quebec, Canada.

Lopez, M.V. and Satti, S.M.E. (1996.) Calcium and potassium enhanced growth and yield of tomato under sodium chloride stress, Plant Sci., 144: 19-27.

Maria, I.S.; Nora, F. and Atilio, J.B. (2002). The effect of inoculation with Azospirillum brasilense on growth and nitrogen utilization by wheat plants. Plant Soil, 245: 215-222.

Martinez, V. and Cerda, A. (1989). Influence of $\mathrm{N}$ source on rate of $\mathrm{Cl}, \mathrm{Na}$, and $\mathrm{K}$ uptake by cucumber seedings grown in saline conditions, J. Plant Nutr., 12: 971-983.

Muchovej, R. (2004). Importance of Mycorrhizae for Agricultural Crops. SSAGR-170. Florida: Agron. Dept.,
Florida Cooperative Extension Service, Inst. Food and Agric. Sci., Univ. Florida.

Pessarakli, M. and Tucker, T.C. (1988). Dry matter yield and nitrogen-15 uptake by tomatoes under sodium chloride stress. Soil Sci. Soc. Am. J., 52: 698700 .

Quilambo, O.A. (2000). Functioning of peanut (Arachis Hypogaea L.) under nutrient deficiency and drought stress in relation to symbiotic association. Univ. Groningen, the Netherlands.

Rodringuez, H. and Fraga, R. (1999). Phosphate solubilizing bacteria and their role in plant growth promotion. Biotechnol. Adv., 17: 319-339.

Ruiz-Lozano, J.M.; Azcón, R. and Gómez, M. (1996). Alleviation of salt stress by arbuscular mycorrhizal glomus species in lactuca sativa plants. Physiol. Plant, 98: 767-772.

Shrivatava, P. and Kumar, R. (2015). Soil salinity: A serious environmental issue and plant growth promoting bacteria as one of the tools for its alleviation. Saudi J. Biol. Sci., 22 (2): 123-131.

Snedecor, G.W. and Cochran, W.G. (1980). Statistical Methods. $7^{\text {th }}$ Ed. Iow State Univ. Press, Ames Iowa, USA.

Steel, R.G.D. and Torrie, J.H. (1960). Principles and Procedures of Statistics. McGraw-Hill Book Company, Inc., New York.

Voogt, W. (1987). The growth of beefsteak tomato as affected by $\mathrm{K} / \mathrm{Ca}$ rations in the nutrient solution, Acta Hort., 222: 155165.

Wu, S.C.; Cao, Z.H.; Li, Z.G.; Cheung, K.C. and Wong, M.H. (2005). Effects of biofertilizer containing $\mathrm{N}$ fixer, $\mathrm{P}$ and $\mathrm{K}$ Solubilizers and AM fungi on maize growth, a greenhouse trial. Geoderma, 125: 155-166. 
SINAI Journal of Applied Sciences (ISSN: 2314-6079) Vol. (8) Is. (2), Aug. 2019

Yaseen, T.; Burni, T. and Hussain, F.

(2011). Effect of arbuscular mycorrhizal inoculation on nutrient uptake, growth and productivity of cowpea (Vigna unguiculata) Varieties. Afr. J. Biotechnol., 10 (43): 8593-8598. 
تأثيـر الـريـزوبكتيريـا المحفزة للنمو ومسـتويات الملوحة علي نمو نبات الطماطم باستخدام تقتيـة ن 10

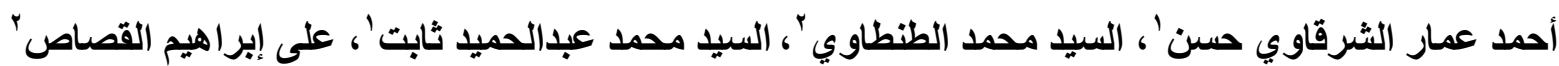
ا ـ قسم البحوث النباتية، مركز البحوث النووية، هيئة الطاقة الذرية، مصر. r ـ قسم الإنتاج النباتي، كلية العلوم الزر اعية البيئية، جامعة العريش، مصر.

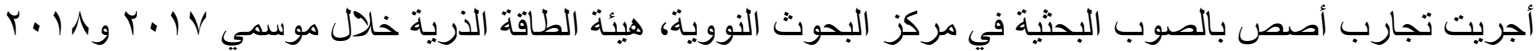

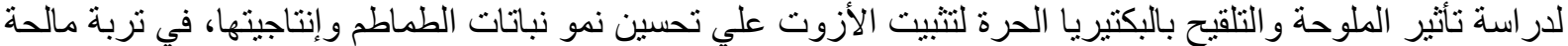

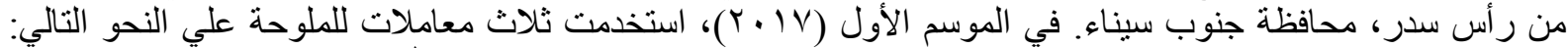

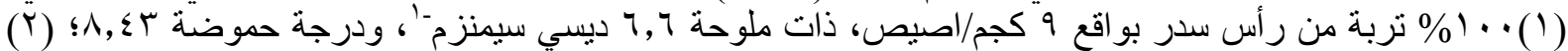

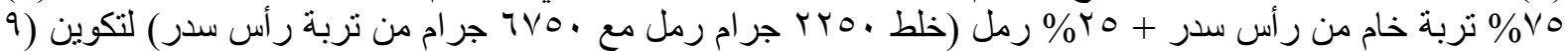

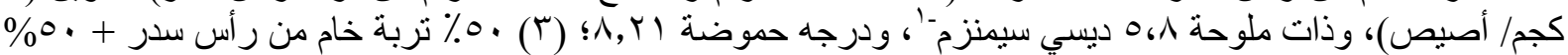

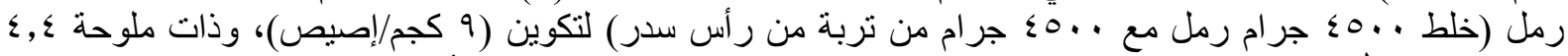

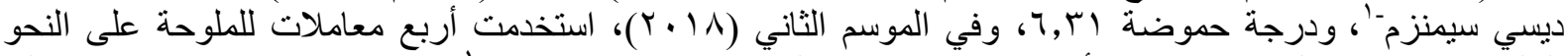

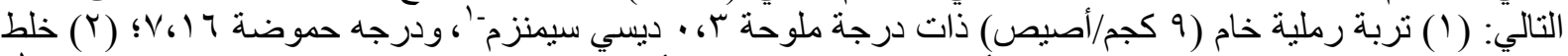

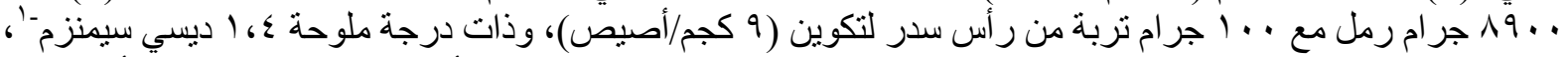

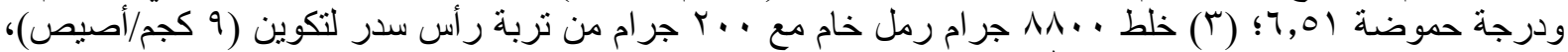

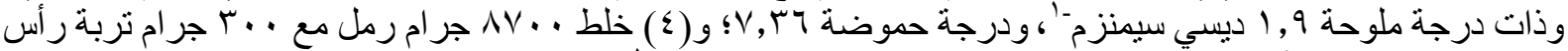

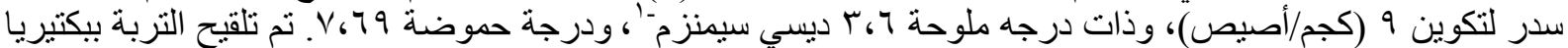

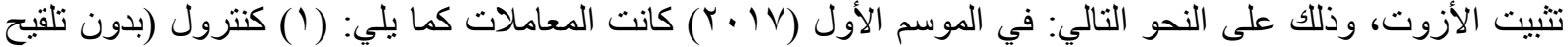

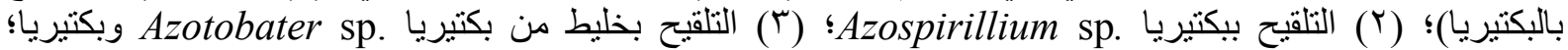
Azospirillium sp.

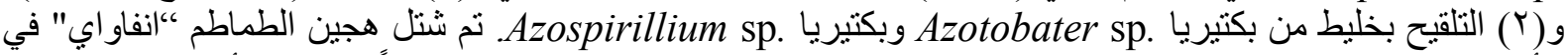

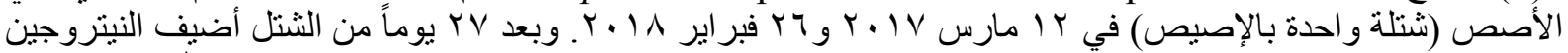

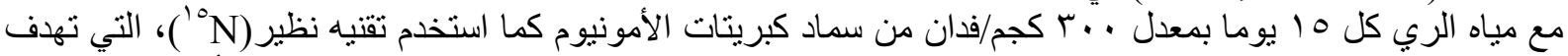

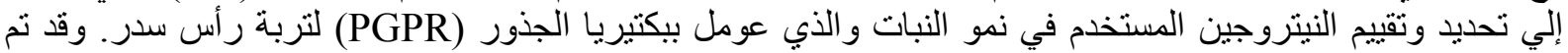

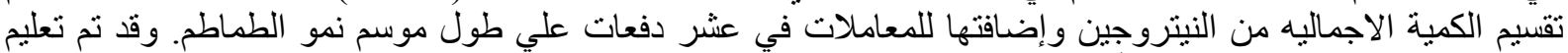

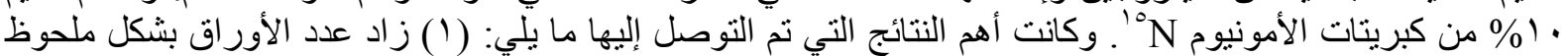

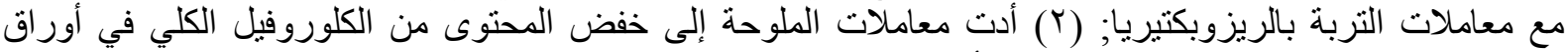

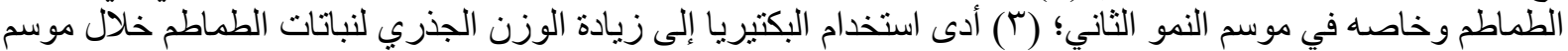

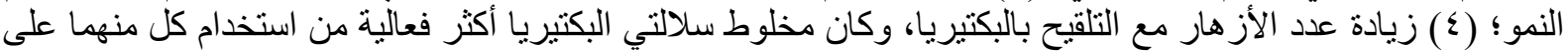

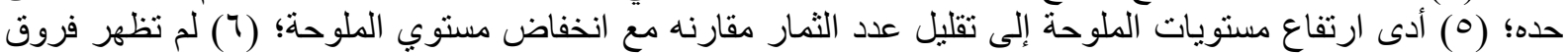

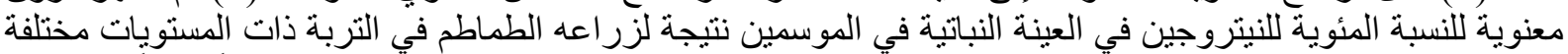

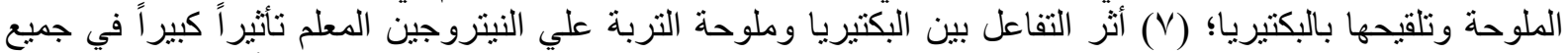

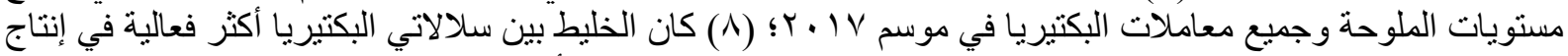

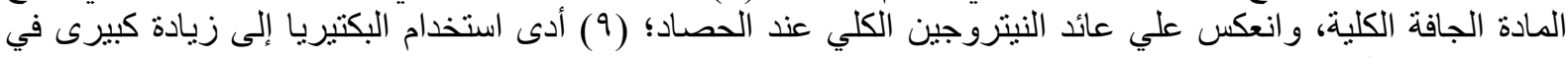
كفاءة استخدام النبتروجين. الكلمات الإسترشادية: الريزوباكتيريا، الملوحة، محفزات نمو النبات، النيتروجين المعلم. 